\title{
Immunomodulating potential of Neolamarckia cadamba (Roxb.) Bark extract
}

\author{
Vishal Khandelwal* (D) and Pradeep Kumar Choudhary (D) \\ Department of Biotechnology, GLA University, Mathura - 281 406, India.
}

\begin{abstract}
Neolamarckia cadamba (Roxb.) Bosser Miq., holistic tree, well narrated in Charak Samhita and Sushrut Samhita. Traditionally different parts of $\boldsymbol{N}$. cadamba has been used by many communities and tribes to treat sour throat, cough, fever, infections and inflammation. Present work concern with study of immunomodulatory activities of hydro-methanolic extract (HME) of $N$. cadamba bark with reference to humoral and cell mediated immune responses of experimental animals. On the basis of mean body weight (g) of Wistar albino rats, their healthy status, change in their behavior, skin and fur texture, four groups- Group-I (control), Group-II (125 mg/kg HME), Group-III (250 mg/kg HME) and Group-IV (500 $\mathrm{mg} / \mathrm{kg} \mathrm{HME}$ ) containing six animals each were made to determine mean serum antibody titer of treated and control groups against Salmonella typhimurium ' $O$ ' antigen using indirect ELISA. Determination of in vitro cell mediated immune response was done by MTT assay using optimum concentration ( 5 $\mu \mathrm{g} / \mathrm{mL})$ Con A with various concentration of $\mathrm{HME}(20-500 \mu \mathrm{g} / \mathrm{mL})$. Result suggested various doses of HME $(125 / 250 / 500 \mathrm{mg} / \mathrm{kg}$ b.wt) causes significant increase $(p<0.01)$ in antibody titer when compared to the control group, which concludes enhanced humoral immune response. Result suggested that different concentrations of HME bring about significant increase $(p<0.01)$ in proliferation of splenocytes, depicting enhanced cell mediated immune response. Study concludes immunostimulatory potential of HME of $N$. cadamba bark and can be possibly used in drug and food preparation.
\end{abstract}

Keywords: Humoral immune response, cell mediated immune response, MTT, ConA

*Correspondence: vishal_k80@rediffmail.com

(Received: January 18, 2020; accepted: March 23, 2020)

Citation: Vishal Khandelwal and Pradeep Kumar Choudhary, Immunomodulating potential of Neolamarckia cadamba (Roxb.) Bark extract, J. Pure Appl. Microbiol., 2020; 14(1):641-646. https://doi.org/10.22207/JPAM.14.1.66

(C) The Author(s) 2020. Open Access. This article is distributed under the terms of the Creative Commons Attribution 4.0 International License which permits unrestricted use, sharing, distribution, and reproduction in any medium, provided you give appropriate credit to the original author(s) and the source, provide a link to the Creative Commons license, and indicate if changes were made. 


\section{INTRODUCTION}

Plant derived products and their derivatives have been the most successful source of drug leads ${ }^{1}$. In spite of popularity of the synthetic products due to its production cost, time effectiveness, easy quality control, stringent regulation and quick effects in recent decades, their safety and efficacy has always remained questionable. Natural products still make a significant contribution to health care because of its time tested safety and efficacy ${ }^{2,3}$. Recent advancement in natural product drug discovery has resulted in compounds that are being developed to treat cancer, viruses and resistant bacteria and immunosuppressive disorders ${ }^{4}$. Further, clinical trials are ongoing on more than 100 natural product derived drugs and at least 100 molecules/ compounds are in preclinical development stage highlighted the existing viability and significance of the use of natural products as sources of new drug candidates ${ }^{5,6}$.

The immunomodulatory properties of plants are being studied broadly with everincreasing interest due to the benefits by immune system modulation for disease prevention and treatment in recent years ${ }^{7}$. These findings have now given many empirical therapies a rationale, scientific basis and thereby a means for 'intelligent' development ${ }^{8}$. Immunomodulatory potential of 100 plants have been investigated in India by studying the mechanism of immune system and involvement of cytokines at molecular level ${ }^{9}$. Immunomodulatory plants in our Classics are Tinospora cordifolia (Guduchi), Emblica officinalis (Amalaki), Terminalia chebula (Haritaki), Glycyrrhiza glabra (Yashtimadhu), Commiphora mukul (Guggul), Allium sativum (Lahsuna), Withania somnifera (Ashwagandha), Azardicta indica (Neem), Asparagus racemosus (Shatavari), Samecarpus anacardium (Bhallatak), Piper longum(Pippali), Aloe vera(Ghritkumari), Boerhaevia diffusa (Punarnava), Ocimum sanctum (Tulasi), and Shilajit (Asphalt) ${ }^{10}$.

Neolamarckia cadamba is one of such important medicinal plants belonging to the Rubiaceae family. In traditional Indian system of medicine, it has been used to treat fever, uterine complaints, blood diseases, skin diseases, eye inflammation, anemia, diarrhea, leprosy, dysentery and stomatitis ${ }^{11}$. It has the largest number of phytochemicals and secondary metabolites (viz., cadambagenic acid, cadamine, quinovic acid, $\beta$-sitosterol, cadambine, etc.) having various biological and pharmacological properties ${ }^{12}$. Neolamarckia cadamba has a wide spectrum of biological activities including anti-inflammatory ${ }^{13}$, anti-helminthic ${ }^{14}$, antioxidant ${ }^{15}$, and antihepatotoxic activities ${ }^{16}$. However, no study to date has investigated the immunomodulatory role Neolamarckia cadamba bark extract.Therefore, the present study has been designed to study immunomodulatory potential of hydromethanolic extract of $N$. cadamba bark.

\section{MATERIALS AND METHODS Experimental animals}

Wistar albino rats weighing 80-100 g were procured from animal house, IPR, GLA University, Mathura. Four groups containing six animals were made. Animals of Group-II, III \& IV were fed orally with $125,250,500 \mathrm{mg} / \mathrm{kg}$ body weight of HME of N. cadmba bark respectively while control group (Group-I) animals were orally fed with rat pellet and water ad libitum for 21 days.

\section{Chemicals}

Freund's complete adjuvant (FCA), Freund's incomplete adjuvant (FIA), Concanavalin A (Con A), 3-(4,5-dimethylthiazol-2-yl)-2,5diphenyltetrazolium bromide (MTT), trypan blue, were procured from Sigma chemicals Co, USA and Anti rat IgG-HRP conjugate antibody was obtained from Thermo Scientific, USA.

\section{Plant material}

Neolamarckia cadamba bark was gathered from Mathura $\left(27^{\circ} 31^{\prime} 2^{\prime \prime} \mathrm{N}-77^{\circ} 39^{\prime} 26^{\prime \prime} \mathrm{E}\right)$. Identification and authorization of plant material was done by Dr. A. S.Updadhye, Agharkar Research Institute, Pune with voucher deposition No. L-084. Dried bark powder was used in preparation of hydo-methanolic extract (HME) of N. cadamba.

\section{Preparation of extract}

Coarsely powdered bark (300-350 g) was taken in soxhlet apparatus in presence of hydromethanolic $(80: 20, \mathrm{v} / \mathrm{v})$ solvent and subjected to boil at $65^{\circ} \mathrm{C}$ for $8-10 \mathrm{hrs}$. Evaporation was done at controlled temperature and reduced pressure using rotary evaporator. Finally, dark brown crystals (\% yield: 14$)$ were obtained. 


\section{Experimental animal}

Wistar albino rats (80-100 g) were taken from central animal house, GLA University, Mathura and used for immunomodulatory studies. Ethical clearance was obtained with IAEC approval vide GLAIPR/CPCSEA/IAEC/2014/Biotech/02. Four groups (Groups-I, II, III \& IV) containing six animals each were made for assessment of in vivo humoral immune response.

Determination of safe and non-toxic dose of HME of $N$. cadamba

To determine the safe and non-toxic dose of hydro-methanolic extract (HME) of N. cadamba, four groups of Wistar albino rats, comprising six rats in each group were made. Safe dose level was determined according to Organization for Economic Co-operation and Development guidelines No. $423^{17}$. Animals of Group-II, III \& IV were fed orally with 125, 250, $500 \mathrm{mg} / \mathrm{kg}$ b.wt respectively for twenty one days whereas animals of Group-I (control) were fed with rat pellet and water ad libitum. All the groups of albino rats were monitored for the development of clinical signs, changes in physical health conditions and body weight.

\section{Apparent heath condition and toxic signs}

Rats of test groups (HME fed rats and unfed rats) were kept separately and observed every day for any toxic sign / symptoms / abnormal changes throughout the experiment. The dose causing no adverse effect was taken as safe and nontoxic dose (NTD) for further studies.

\section{Body weight gain/loss}

Animals fed with different doses of HME of bark including control group were weighed at weekly interval and the mean body weight was recorded at 0 and 21st day. The mean body weight of rats of test groups was recorded and compared with the control group.

Measurement of antibody titre for determination of humoral immune response

Salmonella typhimurium ' $O$ ' antigen was prepared as per method suggested ${ }^{18}$. Smooth colonies of $S$. typhimurium grown on Tryptose agar medium were selected and inoculated in nutrient broth. Inoculated broth was incubated for 6-8 hours at $37^{\circ} \mathrm{C}$ and then boiled at $100^{\circ} \mathrm{C}$ for two hours thirty minutes. Heated $S$. typhimurium culture was used as ' $\mathrm{O}$ ' antigen for determination of humoral immune response in rats. Antibodies were raised against animals of all groups subcutaneously immunized with Salmonella typhimurium ' $O$ ' antigen. On 1st day, all animals of Group-I (control), Group-II (125 mg/kg b.wt), Group-III (250 mg/ kg b.wt) and Group-IV (500 mg/kg b.wt) were subcutaneously immunized with equal volume $(0.5 \mathrm{~mL})$ of $S$. typhimurium “ $\mathrm{O}$ ” antigen $(2 \mathrm{mg} / \mathrm{ml})$ and FCA. Then after at $7^{\text {th }}$ and $14^{\text {th }}$ day all groups including control were immunized with equal volume $(0.5 \mathrm{~mL})$ of $S$. typhimurium " $O$ " antigen and FIA. At 21st day serum from all experimental animals was used for determination of humoral immune response. Antibody titer of experimental and control group animals was determined in accordance to protocol ${ }^{19}$. Assessment of humoral (antibody mediated) immune response was done by conventional indirect ELISA.

Determination of cell mediated immune response Splenocyte preparation

Rat splenocytes preparation was carried out in accordance to method suggested ${ }^{19}$. Spleen was macerated and filterated through nytex membrane to remove large particles. Cells were then resuspended in RPMI-1640 medium containing $10 \%$ fetal calf serum and centrifuged at $2500 \mathrm{rpm}$ for 10 minutes. Centrifuged cell were then treated with $0.15 \mathrm{M} \mathrm{NH}_{4} \mathrm{Cl}$ (lysis buffer) for erythrocytes lysis and then washed with RPMI1640 medium. Cell viability was determined by trypan blue dye ( $0.1 \%$ solution) and viable cell concentration was adjusted to $2 \times 10^{6}$ cells $/ \mathrm{mL}$ by haemocytometer and was used for splenocytes proliferation assay.

In vitro effect of HME of $\boldsymbol{N}$. cadamba bark on splenocytes proliferation/inhibition

Efficacy of HME of $N$. cadamba bark over cell mediated immune response of Wistar albino rats was determined by studying the effect of $\mathrm{HME}$ over rat's splenocytes. $200 \mu \mathrm{L}$ of $2 \times 10^{6}$ spleen cells/ $\mathrm{ml}$ in triplicate seeded with $10 \%$ FBS with $5 \mu \mathrm{g} / \mathrm{ml}$ Con-A (optimum conc.) was cultured in RPMI-1640 medium. Different concentrations 20, 50, 100, 250, $500 \mu \mathrm{g} / \mathrm{mL}$ of HME of $N$. cadamba bark were added in triplicate to respective wells of plate. Incubation of culture plate was carried at $37^{\circ} \mathrm{C}$ for 72 hours using $\mathrm{CO}_{2}$ incubator $\left(5 \% \mathrm{CO}_{2}\right)$. After that $20 \mu \mathrm{L}$ of MTT solution $(5 \mathrm{mg} / \mathrm{mL}$ ) was added to each well. Formation of formazone crystals occurs due to reduction of MTT. Plate was further incubated at $37^{\circ} \mathrm{C}$ for 4 hours in $\mathrm{CO}_{2}$ incubator $\left(5 \% \mathrm{CO}_{2}\right.$ and 
$80 \%$ relative humidity), followed by removal of supernatant. The plate was allowed to dry and formazone crystals were dissolved by adding $100 \mu \mathrm{L}$ DMSO. Mean OD values were determined with respect to control by ELISA reader.

\section{Result and Discussion}

Determination of safe and nontoxic dose of HME of $N$. cadamba

Various doses of HME $(125,250,500 \mathrm{mg} /$ kg body weight) of $N$. cadamba bark was given orally to the respective groups of Wistar albino rats comprising of six rats in each group for 21 days. All the orally fed (Group-II, Group-III and GroupIV) and control (Group-I) groups were kept under regular observations. 125, 250 and $500 \mathrm{mg} / \mathrm{Kg}$ b.wt of $\mathrm{HME}$ of $N$. cadamba were safe and non-toxic and were used in further studies.

Effect of HME of $\boldsymbol{N}$. cadamba bark on apparent health status and toxic sign(s)

All the extract-fed rats were found healthy, showing no significant change in their behavior, skin, and fur texture, impairment in food intake and water consumption and no toxic symptom was observed.

Effect of HME of $N$. cadamba bark over body weight of experimental rats

Body weight of albino rats fed with different concentrations of HME was found to have increased significantly $(p<0.01)$ when compared to those in the control group, this is shown in Table 1.

Effect of HME of $\boldsymbol{N}$. cadamba on humoral immune responses in Wistar albino rat model against $S$. typhimurium "O" antigen

Mean values of serum antibody titer in Group-I, II, III and IV were $1710^{\mathrm{a}} \pm 271.97,3840^{\mathrm{ab}}$ $\pm 572.43,4266.67^{\mathrm{bc}} \pm 539.69$ and $6400^{c} \pm 1280$ respectively as shown in Table 2 . Dose dependent significant increase $(p<0.01)$ in antibody titer was found when compared with the control group.
In vitro effect of HME of $\boldsymbol{N}$. cadamba bark on splenocytes proliferation/inhibition

$20.87,48.87,81.71,159.70 \& 209.06$

percentage proliferation in spleen cell culture was noticed at $20 \mu \mathrm{g} / \mathrm{mL}, 50 \mu \mathrm{g} / \mathrm{mL}, 100 \mu \mathrm{g} / \mathrm{mL}, 250$ $\mu \mathrm{g} / \mathrm{mL}$ and $500 \mu \mathrm{g} / \mathrm{mL} \mathrm{HME}$ respectively (Table 3). Maximum \% stimulation index (209.06) was noticed at $500 \mu \mathrm{g} / \mathrm{mL}$ HME treated spleen cell culture.

Various doses of HME viz. 125/250/500 $\mathrm{mg} / \mathrm{kg}$ b.wt were found to be safe and nontoxic and were used for determination of humoral immune response in Wistar albino rats. Dose dependent significant increase $(p<0.01)$ in serum antibody titer was found in rats orally fed with 125,250 and $500 \mathrm{mg} / \mathrm{kg}$ b.wt. HME of $\mathrm{N}$. cadamba bark with respect to control which is in agreement with previous findings ${ }^{19}$. Presently, enhanced antibody titer suggests that various doses of $\mathrm{HME}$ brings about stimulation and proliferation of $B$ lymphocytes, which play a key role in antibody production $^{20,21}$. Study signifies that oral intake of different doses of HME of $N$. cadamba bark causes augmentation in adaptive immune response of experimental groups, since they are based mainly on the antigen-specific receptors found on the

Table 1. Mean body weight (g) of Wistar albino rats of different Groups

\begin{tabular}{llll}
\hline S. No & Groups & 0 day & 21st day \\
\hline 1 & $\begin{array}{l}\text { Group-I (Control) } \\
\text { Group-II }\end{array}$ & $61.50 \pm 1.67$ & $80.83^{\mathrm{a}} \pm 3.19$ \\
& $\begin{array}{l}(125 \mathrm{mg} / \mathrm{kgb} . w \mathrm{t}) \\
\text { Group-III }\end{array}$ & $66.33 \pm 0.99$ & $95.33^{\mathrm{b}} \pm 3.6$ \\
3 & $\begin{array}{l}\text { (250 mg/kgb.wt) } \\
\text { Group-IV }\end{array}$ & $57.67 \pm 2.3$ & $97.50^{\mathrm{b}} \pm 2.24$ \\
& $\begin{array}{l}\text { (500 mg/kgb.wt) } \\
62.83 \pm 5.35\end{array}$ & $98.83^{\mathrm{b}} \pm 3.19$
\end{tabular}

All values are Mean \pm S.E. of 6 rats. Results are significant at $p$ $<0.01$ as per one way ANOVA followed by DMRT.

Table 2. Determination of Humoral response of Wistar albino rats fed with HME against S .typhimurium 'O' antigen

\begin{tabular}{|c|c|c|c|}
\hline Control & & $\begin{array}{l}\text { Antibody Titer } \\
\text { HAE fed rats }\end{array}$ & \\
\hline $\begin{array}{l}\text { Group-1 } \\
\text { (Control) }\end{array}$ & $\begin{array}{l}\text { Group-2 } \\
\text { (125 mg/kgb.wt) }\end{array}$ & $\begin{array}{l}\text { Group-3 } \\
\text { (250 mg/kgb.wt) }\end{array}$ & $\begin{array}{l}\text { Group-4 } \\
\text { (500 mg/kgb.wt) }\end{array}$ \\
\hline $1710^{\mathrm{a}} \pm 271.97$ & $3840^{a b} \pm 572.43$ & $4266.67^{b c} \pm 539.69$ & $6400^{c} \pm 1280$ \\
\hline
\end{tabular}

The values represent the mean \pm SEM of six rats. Results are significant at $p<.01$ as per one-way ANOVA followed by DMRT.

Journal of Pure and Applied Microbiology 
Table 3. In vitro effect of HME of $N$. cadamba bark on Con-A stimulated Wistar albino rat splenocytes proliferation/inhibition

\begin{tabular}{lll}
\hline $\begin{array}{l}\text { Spleen cell } \\
\text { culture }\end{array}$ & Mean & $\begin{array}{l}\% \\
\text { stimulation } \\
\text { index }\end{array}$ \\
\hline
\end{tabular}

Control spleen cells

without extract $\quad 0.0618^{\mathrm{a}} \pm 0.00151$ -

with $20 \mu \mathrm{g} / \mathrm{mL} \mathrm{HME} \quad 0.0747^{\mathrm{b}} \pm 0.0013320 .87$

with $50 \mu \mathrm{g} / \mathrm{mL} \mathrm{HME} \quad 0.092^{\mathrm{c}} \pm 0.00103 \quad 48.87$

with $100 \mu \mathrm{g} / \mathrm{mL} \mathrm{HME} \quad 0.1123^{\mathrm{d}} \pm 0.0055281 .71$

with $250 \mu \mathrm{g} / \mathrm{mL} \mathrm{HME} \quad 0.1605^{\mathrm{e}} \pm 0.00134159 .70$

with $500 \mu \mathrm{g} / \mathrm{mL} \mathrm{HME} \quad 0.1910^{f} \pm 0.00393209 .06$

The values represent the mean \pm SEM of six rats. Results are significant at $p<.01$ as per one-way ANOVA followed by DMRT.

surfaces of T- and B-lymphocytes ${ }^{22}$. Current study depicts immunomodulatory activity of HME of $N$. cadamba bark.

Current study deal with in vitro effect of different doses of $\operatorname{HME}(20,50,100,250,500 \mu \mathrm{g} /$ $\mathrm{mL}$ ) over spleen cell culture. Maximum stimulation index (\%) was noticed with $500 \mu \mathrm{g} / \mathrm{mL}$ HME of bark of $N$. cadamba (Table 3). Dose dependent significant $(p<0.01)$ increase in proliferation of splenocytes was found at 20, 50, 100, 250 and $500 \mu \mathrm{g} / \mathrm{mL}$ conc. of HME of $N$. cadamba. Present findings on splenocytes proliferation are in concurrence with previous study ${ }^{23}$.

Current study revealed escalation in humoral and cell mediated immune in experimental animals suggesting immunostimulatory potential of hydro-methanolic extract of $N$. cadamba bark and can therefore serve as herbal remedy to enhance immune responses in immunodeficient individuals.

\section{CONCLUSION}

Present study concludes synergistic effect of HAE of $N$. cadamba bark, responsible for enhancement of humoral and cell mediated immunity and can serve as remedy in treatment of immunodeficiency disorders. Moreover, there is a need to isolate and characterize the novel compound(s) present in $N$. cadamba bark extract responsible for enhanced immune response.

\section{ACKNOWLEDGEMENTS}

Authors express their thanks to Director,
Institute of Applied Sciences and Humanities, GLA University, Mathura for providing necessary facility.

\section{CONFLICTS OF INTEREST}

The authors declare that there is no conflict of interest.

\section{AUTHORS' CONTRIBUTION} equally.

VK and PK contributed significantly and

\section{FUNDING}

None.

\section{DATA AVAILABILITY}

All datasets generated or analyzed during this study are included in the manuscript.

\section{ETHICS STATEMENT}

Ethical clearance was obtained with IAEC approval vide GLAIPR/CPCSEA/IAEC/2014/ Biotech/02.

\section{REFERENCES}

1. Koehn, F.E., \& Carter, G.T. The evolving role of natural products in drug discovery. Nature reviews Drug discovery., 2005; 4(3): 206-220. https://doi. org/10.1038/nrd1657

2. Calixto, J.B. Efficacy, safety, quality control, marketing and regulatory guidelines for herbal medicines (phytotherapeutic agents). Brazilian journal of medical and biological research., 2000; 33(2): 179-189. https:// doi.org/10.1590/S0100-879X2000000200004

3. Veeresham, C. Natural products derived from plants as a source of drugs. Journal of advanced pharmaceutical technology \&research.,2012;3(4): 200-201. https:// doi.org/10.4103/2231-4040.104709

4. Gullo, V.P., McAlpine, J., Lam, K.S., Baker, D., \& Petersen, F. Drug discovery from natural products. Journal of Industrial Microbiology and Biotechnology., 2006;33(7): 523-531. https://doi.org/10.1007/s10295006-0107-2

5. Harvey, A.L. Natural products in drug discovery. Drug discovery today., 2008; 13(19): 894-901. https://doi. org/10.1016/j.drudis.2008.07.004

6. Katiyar, C., Gupta, A., Kanjilal, S., \&Katiyar, S. Drug discovery from plant sources: An integrated approach.Ayu., 2012; 33(1): 10-19. https://doi. org/10.4103/0974-8520.100295

7. Murugananthan, G., Mohan, S., Pabbithi, S.C., \&Debanjan, D. Immunomodulatory constituents from plant origins: a review of isolated biomolecules. International Journal of Pharmaceutical Sciences and Research., 2013; 4(7): 2459-2469.

8. Kayser, O., Masihi, K.N., \&Kiderlen, A.F. (2003). 
Natural products and synthetic compounds as immunomodulators. Expert review of antiinfective therapy.,2003; 1(2): 319-335. https://doi. org/10.1586/14787210.1.2.319

9. Mukherjee, P.K., Nema, N.K., Bhadra, S., Mukherjee, D., Braga, F.C., \&Matsabisa, M. G. Immunomodulatory leads from medicinal plants. Indian Journal of Traditional Knowledge., 2014; 13(2): 235-256. https:// doi.org/10.1016/B978-0-12-397153-1.00022-6

10. Singh, B.P.,\&Deepa. Concept of Immunomodulation in Ayurveda and Some Immunomodulatory Herbs. International Ayurvedic Medical Journal.,2015; 3(7): 2206-2212.

11. Dubey, A., Nayak, S., \&Goupale, D.C. A review on phytochemical, pharmacological and toxicological studies on Neolamarckiacadamba. Der Pharmacia Lettre.,2011; 3(1): 45-54.

12. Dwevedi, A., Sharma, K., \& Sharma, Y.K. Cadamba: A miraculous tree having enormous pharmacological implications. Pharmacognosy Reviews., 2015; 9(18): 107-113. https://doi.org/10.4103/0973-7847.162110

13. Chandrashekar, K.S., Prasanna, K.S., \&Abinash, B. Anti-inflammatory effect of the methanol extract from Anthocephalus cadamba stem bark in animal models. International Journal of Plant Biology., 2010; 1(1): 3032. https://doi.org/10.4081/pb.2010.e6

14. Acharyya, S., Rathore, D.S., Kumar, H.K. \& Panda, N. Screening of Anthocephalus cadamba (roxb.) miq. root for antimicrobial and anthelmintic activities. International Journal of Pharmaceutical and Biomedical Sciences.,2011; 2: 297-300.

15. Umachigi, S.P., Kumar, G.S., Jayaveera, K.N., Kishore, K.D., Ashok, K.C. \&Dhanapal, R. Antimicrobial, wound healing and antioxidant activities of Anthocephalus cadamba. African journal of traditional, complementary and alternative medicines., 2007; 4(4): 481-487. https://doi.org/10.4314/ajtcam.v4i4.31241

16. Kapil, A., Koul, I.B. \&Suri, O.P. Antihepatotoxic effects of chlorogenic acid from Anthocephalus cadamba. Phytotherapyresearch.,1995; 9(3): 189-193. https:// doi.org/10.1002/ptr.2650090307

17. OECD, (2000). Guidelines for the Testing of Chemicals Revised Draft Guideline 423: Acute Oral Toxicity.

18. Goel, A., Kumar, D.\& Bhatia, A.K. Modulation of immune responses of aqueous extract of Argemone mexicana leaves. Journal of immunology and immunopathology., 2008; 10(1): 65-69.

19. Khandelwal, V., Choudhary, P.K., Goel, A., Bhatia, A.K., Gururaj, K., Gupta, S. \& Singh, S.V. Immunomodulatory activity of Neolamarckia cadamba (Roxb.) Bosser with reference to IL-2 induction. Indian journal of Traditional Knowledge., 2018; 17(3): 451-459.

20. Lund, F.E., Garvy, B.A., Randall, T.D. \& Harris, D.P. Regulatory roles for cytokine-producing $B$ cells in infection and autoimmune disease. Current directions in autoimmunity., 2005;8:25-54. https:// doi.org/10.1159/000082086

21. Pistoia, V. Production of cytokines by human B cells in health and disease. Immunology Today., 1997; 18(7):343-350. https://doi.org/10.1016/S01675699(97)01080-3

22. Chaplin, D.D. Overview of the immune response. Journal of allergy and clinical immunology.,2010; 125(2): S3S23. https://doi.org/10.1016/j.jaci.2009.12.980

23. Khandelwal, V., Choudhary, P.K., Goel, A., Bhatia, A.K., Pant, G., Chaubey, K.K., Gupta, S. \& Singh, S.V. Cytokines modulating potential of Neolamarckiacadamba (Roxb.) Bosser. Indian journal of Traditional Knowledge., 2019; 18(1): 88-93. https://doi.org/10.4103/09719261.109368 